\title{
$\begin{array}{lllllll}M & \text { U } & \text { S } & \text { I } & \text { C } & \text { S }\end{array}$
}

\section{INDONESIAN MUSIC-CULTURE AS A PERSONAL AND RESEARCH EXPERIENCE}

\author{
MARZANNA POPŁAWSKA \\ INSTITUTE OF ETHNOLOGY AND CULTURAL ANTHROPOLOGY, \\ UNIVERSITY OF WARSAW
}

\begin{abstract}
In this article, I address music - that is, humanly and purposefully organized sound (Blacking 1973; Shelemay 200I) - as a personal, cultural and research experience. Drawing on my experience of learning, researching and performing Indonesian music, I discuss several issues that are pertinent to the ethnomusicological/anthropological study of non-native music-cultures. I examine the concept of bi-musicality, its challenges and limitations; the role of a phenomenological perspective and hermeneutics in conceptualizing the complexities of music experience and meaning in music; and the role of music in shaping identity, especially at the community level.
\end{abstract}

K E Y W O R D S : ethnomusicology, music anthropology, Indonesian music, Christian music, musical meaning, intonation, reflexivity, experience of music, identity and music

Music constitutes an extremely important sphere of social, cultural and individual human life. It is a "powerful human resource," which is "at the heart of our most profound social occasions and experiences"; music sustains communities, fulfils diverse needs and contributes to social integration (Turino 2008, I). Furthermore, music has a high capacity for emotional expression. It holds a real visceral power and is capable of making specific connections at the deepest level of consciousness (Slobin 1994). Music shapes both individual and group identity. Its symbolic power and " $\mathrm{t}]$ he direct experiences it offers of the body, time and sociability" enable people to "place themselves in "imaginative cultural narratives"' (Frith I996, I24).

In my personal and scholarly life, I have experienced many of music's attributes, inherent qualities and roles: the visceral power of music, its profoundness, participatory social and communal character, feracious creative energy and unique ability to shape identity - both my own and that of the people with whom I worked in the research field. My personal experience of Indonesian music began in Poland: as a student of Warsaw University, I had a chance to learn gamelan music at the Indonesian Embassy 
in Warsaw. ${ }^{\mathrm{I}}$ From that time, I recall the extraordinary auditory and visual experience of witnessing Indonesian dance performed for the first time. Dimmed lights, dazzling colours, tender music, glittering costumes and sublime dance gestures transported me into a kind of subliminal space. I was watching the dance and the performers, and absorbing what was happening with all my senses. This was a very physical response as I could hear, see and feel the music with all my body - accompanied by a feeling of complete awe: this was clearly unlike any kind of music experience I had had thus far. At that moment, I was experiencing the very tangible "visceral power" of music first hand.

From this first, quasi extra-terrestrial, encounter with Indonesian music, my experiences have gradually evolved, reaching a terrain where Indonesian music is not as astonishing or overwhelming. On the contrary, it oftentimes constitutes my daily-life experience: it brings comfort and feels like home. It has become familiar and intimate, but at the same time it is still very special and unlike anything else. As Anne Rasmussen noted, it has truly become a part of life, not just a research topic $(2004,222)$.

\section{MUSIC-CULTURE}

The field experience of a researcher - a music anthropologist or ethnomusicologist - is first of all cultural, but also aural, visual, embodied. The cultural aspect of this experience is determined by the way the discipline and its subject are defined. There are many studies that examine music "in its own terms" - as a "sound fact" a perspective and method that is generally associated with musicology. However, the anthropological perspective that often dominates in ethnomusicological studies can be credited for the large field of studies that treat music as culture and examine it in relation to other activities and domains of social activities.

Ethnomusicology, characterised as the study of music in culture or the study of music as culture (Merriam 1964), looks at music as a way of organizing human activity: one that is deeply embedded in culture and in fact is itself culture. Jeff Titon, an American ethnomusicologist, goes even further when defining the subject of ethnomusicological inquiry: his term music-culture signifies a group's total involvement with music. Therefore, the music anthropologist/ ethnomusicologist investigates both elements of music organisation (sound and structure) and the place music occupies in human life (ideas, actions, material objects, institutions). The researcher examines

I The term gamelan is used for various types of ensembles (or orchestras) present throughout the Indonesian archipelago, which vary in size, function, musical style and instrumentation. The bestknown gamelan ensembles are in Java and Bali. The central-Javanese gamelan consists of many different instruments, mainly metal (primarily bronze): horizontally and vertically suspended gongs, gong-chimes, single- and multi-octave slab (key) metallophones, and also xylophones, drums, bamboo flutes, bowed and plucked chordophones, and (male and female) singers. 
a group's involvement with music on various levels: individual, family, community, regional and national. From this standpoint, ethnomusicology as a discipline becomes "the study of people making music." This "making" is understood both as people producing the sounds they call music, and constructing the idea of music or the cultural domain that is demarcated as music (Titon 2008, 4I).

Indonesian music-culture is very diverse in terms of ethnically and culturally distinctive groups ${ }^{2}$, as well as in terms of music genres and styles. I have had contact with various kinds of Indonesian music, originating from Sumatra, West Java, Jakarta, Bali, Sumbawa, Flores and East Timor. However, I have had the longest relation with music of central Java, cultivated in the courts of Yogyakarta and Surakarta and at the Indonesian Institutes of Arts in these cities.

After researching traditional Javanese music and its contemporary formal (government) and informal (private) education, I then turned to the music of Indonesian Christians, who comprise about IO\% of the population (ca. $25 \mathrm{mln}$ people). Fascinated by the phenomenon of the presence of traditional (ethnic/local) music in Catholic and Protestant Churches, I embarked on a research and personal journey investigating two contrasting examples, one a central-Javanese Christian community (a minority group in a Muslim majority setting) and the other a Catholic community on Flores (a small island, with very little Muslim presence, in the predominantly Christian East Indonesian province). In my research, I used classic anthropological qualitative research methods complemented by experiential and performative approaches to music, which I discuss in more detail in the subsequent section.

\section{THE EXPERIENCE OF MUSIC AND A PHENOMENOLOGICAL APPROACH}

Ethnomusicological inquiry necessitates not only honed analytical and methodological skills, but also a very practical, experiential and embodied involvement with the music one studies. Since the 196os, when American ethnomusicologist Mantle Hood introduced bi-musicality as one of the essential abilities to be acquired by a music researcher studying non-European cultures, the practical knowledge of the music that one researches has become an increasingly common norm. ${ }^{3}$ Ethnomusicologists were able to capitalize on their bi-musicality by carrying out "truly participatory

2 Indonesia is home to over 600 ethnic groups (2010 Census).

3 Mantle Hood (I9I8-2005) established the very first formal ethnomusicology program at the University of California in Los Angeles (UCLA) by founding the Institute of Ethnomusicology (196I) and introducing the music of Javanese and Balinese gamelan at the university. The curriculum he created included bringing native performers to instruct students in a range of non-European musical traditions. Hood's students went on to found other similar programs (e.g., at Wesleyan, Michigan, Seattle). 
participant-observation in the field" (Shelemay 2008, I43). The method proposed by Hood positioned ethnomusicologists as "leaders in the ethnography of performance, or performance practice" (Cooley \& Barz 2008, 20). Eventually, despite its limitations, bi-musicality "has come to be widely understood as a way of expressing musical competence in disparate styles" (see Cottrell 2007, IOI).

Mantle Hood strongly believed that "the training of ears, eyes, hands and voice" (1960, 55) gives a window to music theory and theoretical understanding. In his approach, he was much less concerned that extensive training in Western music, which many ethnomusicologists have, constrains them in studying other traditions (Shelmay 2008, I42). Among impediments that might hinder understanding of Javanese music-culture at the early stage are issues of musical system and intonation. The physical properties of the sound, especially pitch, are essential to music. The selection and adjustment of pitches - tuning and intonation - are elements that very often distinguish a given music-culture. The intonation and tuning used in Javanese gamelan music is unique and considerably differs from that of Western music.5

The two major tuning systems of central Javanese gamelan are slendro and pelog. On the fixed-pitch instruments of the gamelan, slendro is tuned as a pentatonic (five-tone) scale; its intervals fall between a Western major second and minor third. The singers and rebab (bowed lute) may occasionally play extra pitches. Pelog contains seven tones, which are in fact a source of two other pentatonic scales that use intervals located between a Western half-tone and whole tone, as well as intervals larger than a Western major second (see fig. I). An additional intonational challenge is posed by the fact that different gamelan sets usually have somewhat different tuning, which calls for self-adjustment, especially on the part of singers and rebab players.

Other elements of the Javanese music system which differ conceptually from Western (classical) music are: the cyclic character of the music structures; the importance of improvisation and variation of melodic and rhythmic patterns (that requires developed improvisatory skills); and differing norms of music accentuation (the emphasis is on the fourth note in the four-note units, not on the first, as is the norm in Western music).

The differing (from Western) principles governing sound in gamelan music require a Western musician to surpass his/her assumptions, preconceived notions and conviction that what $s /$ he had learned is "natural" and "universal." Studying Javanese gamelan music involves questioning and subsequently abandoning a musical order which had been well known, but which subsequently becomes not self-evident anymore in the face of different musical norms and logic.

4 See Performing Ethnomusicology (2004), edited by Ted Solis, which gives an account of various performative aspects and approaches in ethnomusicological work.

5 See Marc Perlman (1994) for an in-depth analysis and comparison of western and Indonesian/ Javanese intonation. 


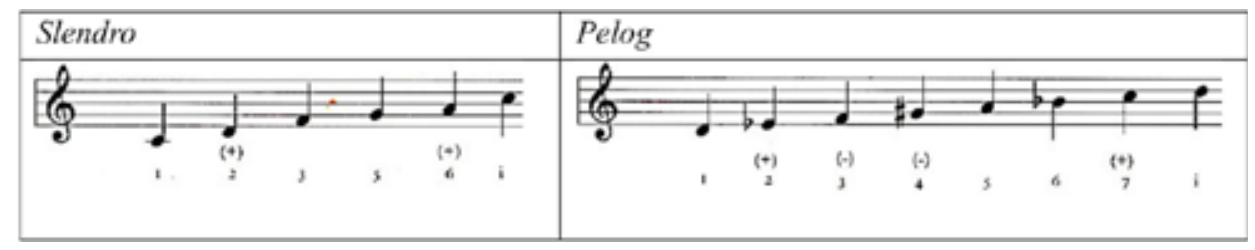

Approximate intervals of Javanese scales: slendro and pelog. "Plus" indicates a slightly higher and "minus" slightly lower pitch than that of a Western scale

Learning about Indonesian music-culture through formal classes I attended at art schools, private music and dance lessons, informal rehearsals with various groups (foreign, mixed and Javanese), music sessions, concerts, dance performances and music festivals, as well as through my own performing in a variety of contexts have all been very important parts of my fieldwork experience in Indonesia and beyond. With time, through intense and comprehensive study, I have acquired an embodied knowledge of Indonesian culture - in terms of music, dance and social skills - that I have absorbed and internalized. I can self-identify as a performing ethnomusicologist who teaches and researches through performance, in addition to other (more or less) conventional anthropological methods.

Studying, learning and comprehending a music-culture (non-native or other) is a life-long process. Nevertheless, this process is not all about learning. Once "inside" the music-culture, the ethnomusicologist assumes also other roles: that of a culture bearer $^{6}$ and those related to the preservation, replication and active transmission of tradition (Shelemay 2008, 150). The researcher fulfils these roles in a constant dialogue with native masters, fellow musicians and scholars, students and various audiences.

\section{INSIDER, OUTSIDER, OR SOMEONE ELSE?}

The relation of a music anthropologist/ethnomusicologist to the music-culture s/he studies is a complex one. Marcia Herndon (1993) problematized the dichotomy of competence and understanding between the insider and outsider, or emic and etic perspectives. Being of mixed-blood Cherokee heritage, Herndon claimed a possibility of speaking as herself: "neither fully insider nor outsider, neither fully emic nor fully etic" (77). Similarly, Tim Rice asserts: "I am neither insider nor outsider; I speak as myself, a self formed, reconfigured, and changed by my encounters with and understandings of Bulgarian, and indeed all kinds of other, musical works and performances" $(2008,57)$. Rice, while describing his involvement with Bulgarian music, goes beyond

6 See Rasmussen (2004) conveying her experience of Middle Eastern music. 
the emic — etic dichotomy by reaching for the philosophy of Ricoeur and making use of the concept of the "hermeneutical arc". He points out that in terms of music the hermeneutical arc begins with "pre-understandings of music, either as a performer or as a listener who finds it coherent, and passes through a structural explanation of music as sound, behaviour, and cognition, to arrive at an interpretation and new understanding of the world or culture referenced by music acting as a symbol." The arc provides "an interpretation of the world that music references by a self operating within finite but expandable horizons" (56). Hermeneutical arcs may "mediate between method and experience and between explanation and understanding by moving through time" (6I). Anyone may use the hermeneutical arc to move "from pre-understandings to explanation to new understandings" (58). Such arcs are very effective in explaining and depicting experience; they portray inward and outward movement, providing "a pathway from the outside, with its cultural alienation, toward the inside by means of appropriation and understanding", and one "from the inside, with its cultural engrossment, toward the outside by means of distanciation and explanation" (6I).

Every researcher can identify their own hermeneutical arcs in the on-going experience of music they research and study. For myself, reaching different levels of understanding and musical competence has often been marked by particular moments of "revelation" or specific performative acts. Such moments also indicated my advancement to another level of understanding and musical competence.

When - after studying Javanese gamelan music for a period of time - I began researching music of Indonesian Christians, my previous experience with and appreciation for traditional Javanese music gave me a window onto the musical experience of Javanese Christians, immediately establishing points of convergence and situating myself not as a total stranger but in a somewhat familiar zone. In this way, I was entering the second hermeneutical arc, gradually acquiring an understanding of the role that music plays in consolidating community and shaping communal identity. My general music competency and specific gamelan competency allowed me to join the female (ibu-ibu) gamelan groups at various Catholic churches and multiple vocal groups at Protestant churches (see figs. 2 and 3). Attending rehearsals and performing side by side with church gamelan players and choir members on multiple occasions - from church services to annual celebrations and weddings - gave me multiple opportunities to share the experience of a musical "being-in-the-world" (see Titon 2008, 3I).

\section{ETHNOGRAPHY AND SHARED EXPERIENCE}

Jeff Titon strongly emphasizes the experiential component in the ethnographic process of learning about music-culture. He construes the research "field" as a "shared 


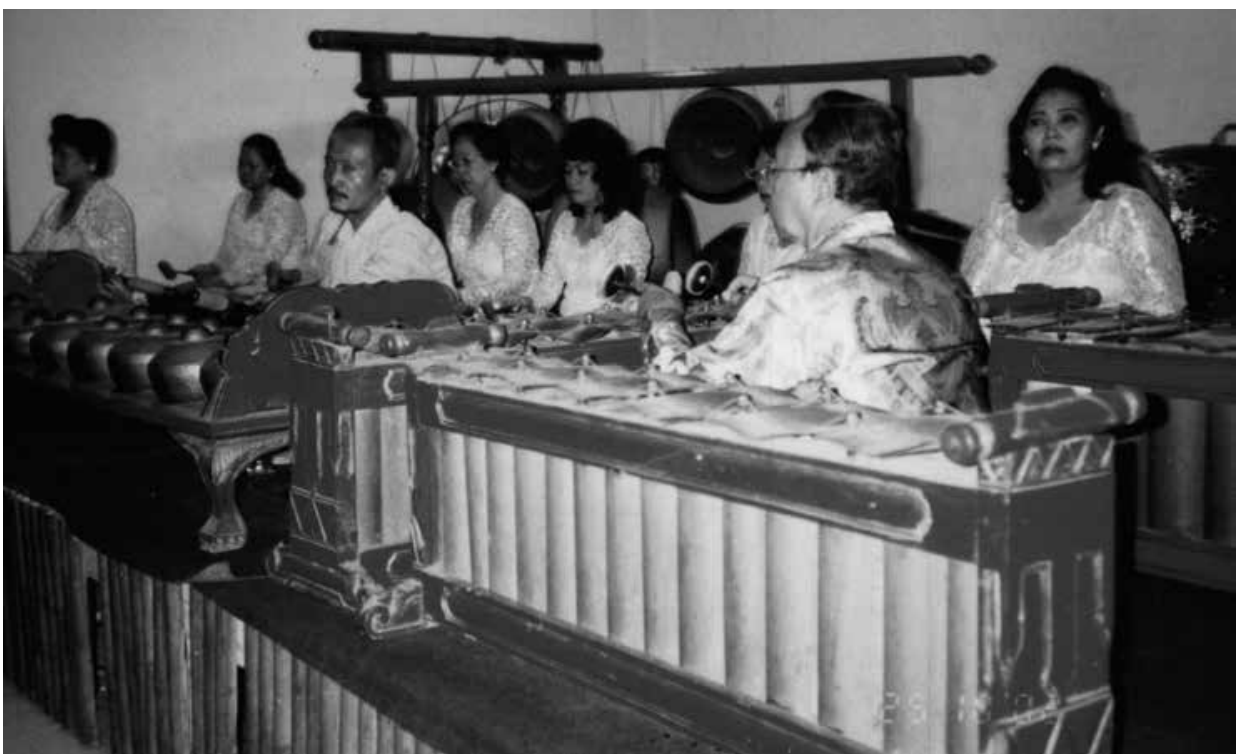

Female (ibu-ibu) gamelan group, with a few male guest players (San Inigo Catholic church, Surakarta)

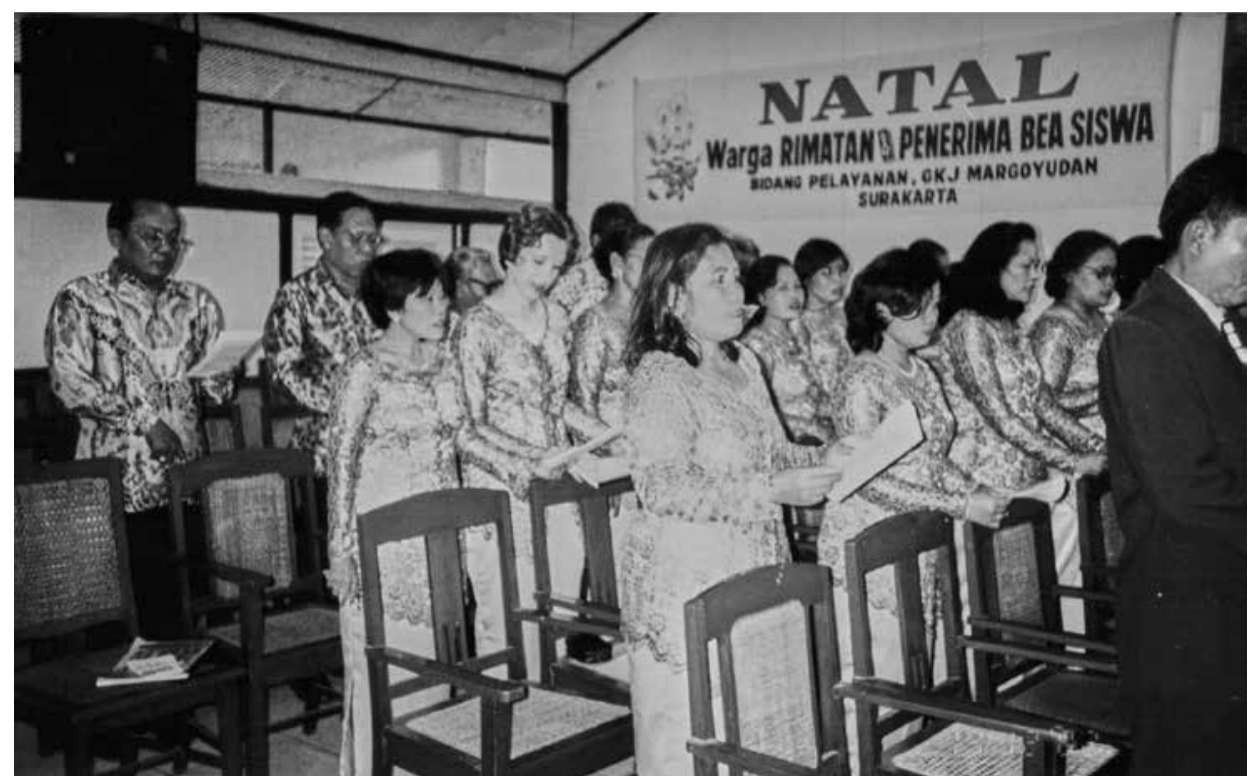

Protestant singing group in the church in Surakarta, with the author 
experience" of playing music with other individuals (Titon 2008, 40). Similarly, Harris Berger, while advocating for phenomenological ethnography, defines its object as "partially shared experience"; its focus being placed on "the commonalties and the differences in the participants' perception of the music" (2008, 7I).

Looking at the precepts for ethnomusicological research methods (see Barz \& Cooley 2008), it does seem that phenomenological ethnography is the desired model for $2 \mathrm{I}^{\text {st }}$ century ethnomusicology. ${ }^{7}$ Berger outlines three tenets of phenomenological ethnography. First, he emphasizes the multiplicity of the object of study: "it is not music sound or music structure, but rather pieces, performances, sounds, or structures in the lived experience of social persons" $(2008,70)$. Second, he highlights the contextuality of the sound/music event: that is "the participant's organization of attention to the music and the situation as a whole." And third, he draws attention to the meaning of sound events: to the affect, style and value that are embedded in experiences of music (7I).

Deborah Wong, on the other hand, emphasizes the specificity of ethnomusicological ethnography (as compared to an anthropological approach) by emphasizing the role of performance. Ethnomusicologists need to be "consistently engaged in the practice of critical ethnography", and at the same time "focus explicitly on creating performative ethnographies while acknowledging the place of autoethnography" in their methodologies $(2008,77)$. She maintains that ethnomusicologists offer "a particular take on ethnography that redirects postmodern and poststructural critical methods." She calls this performative ethnography. Its role is twofold: to convey "the vibrancy and the critical effects" of music and to reflect on the author's own "process of telling, testimony, and cultural critique" (78).

The phenomenological perspective indeed has a great deal of methodological potential thanks to the conceptualization of music as a multidimensional and multifarious, complex "domain of practice," a "realm of activity," shaped by other practices and influential upon them, and a "realm of experience." This perspective allows for tackling fundamental issues in the study of music and culture such as musical meaning, musical interpretation and "the nature of the performance event" (Berger 2008, 20I5). In the subsequent section, I will discuss issues related to meaning in music.

\section{MUSICAL MEANING AND RASA}

Music carries a "complex of ideas, sensations, and associations" (Sullivan 1997, I0). It has a particular capacity to "signify meaning in especially complex ways" (Bohlman in Sullivan 1997, 83). A phenomenological approach to meaning considers it "as actively

7 The critique of this model is pursued by decolonial studies (see, for example, Smith 20I2). 
and socially constituted and differential, though partially shared, across the various participants in a social world" (Berger 2008, 72). Phenomenological approaches to music see "the constitution of meaning in music as an open-ended process": something to be discovered over time through performance of, listening to and reflecting on music. The meaning in music is of an exploratory nature and is shaped through dialogue and reflexive techniques. Music anthropologists/ethnomusicologists "seek to partially share the meanings that their research participants find in social life" (72). Their goal is to "perceive and understand the liminal quality of musical meaning" (Cooley \& Barz 2008, 3), a quality which is often ambiguous. JeffTiton provides the direct link between meaning and experience: it is through a common, inter-subjective experience that the musician-researcher enters the world of interpretation. Consequently, the interpretation turns sound into music, and being into meaning $(2008,32)$.

In the Javanese philosophical and musical tradition, there is a concept that indicates in-depth knowledge, profound understanding and attainment of deeper meaning. This is RASA: a feeling, a sense of taste and above all an aesthetic category ${ }^{8}$. Rasa is semantically complex (see Geertz 1960): it combines two distinct Sanskrit roots. Marc Perlman explicates that: "As 'feeling', rasa refers to the five senses as well as to moods and emotions. As 'meaning', it refers to the semantic aspects of language, especially to the indirect and allusive speech so characteristic of Javanese culture" (1994, 540).

Apart from being defined as "affect, mood, feeling" and taste, rasa also demonstrates perceptive qualities: "as a mental or spiritual capacity [rasa] ranges from the ability to distinguish between various styles to knowledge of inner meaning" (Benamou 20I0, 48). This cognitive aspect of rasa clearly points to an "intuitive perception of inner realities" (Perlman 1994, 540). In its more profound sense, rasa refers to the deepest meaning achieved through mystical efforts.

Marc Perlman emphasizes a duality of the rhetoric of rasa as it relates to musical discourse. On the one hand, rasa allows for a certain creative autonomy from the tradition and the authority of others. On the other hand, there is a sense that not all feelings are equal or similarly valuable (1994, 540). The dual characteristic of rasa makes it evident that both rasa and the inner meaning of music are relative. It is this particular quality of rasa that is "responsible" for differing evaluations of music/sound events and performative acts. Their meaning very much depends on who is doing the evaluation and what kind of subject position s/he occupies? ${ }^{9}$. Differing opinions

8 For an extensive discussion of aesthetics in Javanese music, see Marc Benamou's RASA. Affect and Intuition in Javanese Musical Aesthetics (2010).

9 Marc Perlman points out that in the European tradition, there is a similar duality associated with the category of taste (one of the meanings of rasa). While taste is very much a matter of individual judgment ("there is no disputing about taste"), there is also a concept of "good" and "bad taste," where the former is more valued than the latter (see also Critique of Judgment by Immanuel Kant, I790). 
indicate the existence of a realm of music criticism that - although informal - has real social power.

The aesthetic dimension of rasa ascribes positive value to music that is enak (pleasing) to the ear and compliant with musical sensibility, or cocok (suitable and fitting). Suitability - pleasant and enjoyable sound that brings aesthetic satisfaction - is achieved when a number of components converge into a satisfying whole. These components are musical (such as melody, form or intonation) and extramusical, such as generated emotions and associations.

Rasa is very difficult to attain (especially for a foreigner) and equally difficult to verbalize. It depends on the individual music competency, knowledge, and experience of the performer ${ }^{\mathrm{ro}}$; it generally requires years of studying, listening and performing particular music.

In my research on the music of Indonesian Christians, it became clear that differing preferences and evaluations of the Christian repertoire might be attributed not only to differences in theological perspectives and music competence, but also to varying musical rasa. In turn, differences in rasa lie at the root of differences in musical meaning. Therefore, the meaning of a music event and/or performative act might be different for different participants: a Javanese person singing a Florenese Christian song and a Florenese person singing the very same song may extrapolate different kinds of meanings. For a Florenese, the song may carry various kinds of cultural connotations and associations that may not be fully (or at all) "visible" to a Javanese, and beyond their perception (this is of course true for any ethnic group in a multicultural nation).

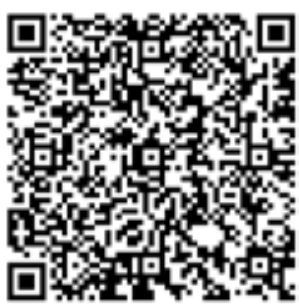

Audio recording 1

The most controversial of traditional genres that I studied in the Javanese Christian context ${ }^{\mathrm{II}}$ was kentrung ${ }^{\text {I2 }}$. Kentrung is an Islamic music genre, as well as an ensemble consisting of frame drums of different sizes, called rebana or terbang $g^{\text {13 }}$. Because of its association with Islam, kentrung's presence in the Christian church is a contested topic. Opinions on kentrung vary significantly. Although

Io See Benjamin Brinner: Knowing Music, Making Music: Javanese Gamelan and the Theory of Musical Competence and Interaction (1995) for a detailed discussion of these issues.

II See the following authors for discussions of Indonesian Christianity and music: Okazaki 1994 (Sumatra-Batak), Aragon 1996 (Sulawesi), Rappoport 2004 (Sulawesi), Manhart 2004 (SumatraNias), Hodges 2009 (Sumatra-Batak), Meka 2012 (Flores) and Wiebe 2017 (Bali).

I2 Audio recording I: Kentrung; a music group from Joyotakan church, Surakarta: https://rcin.org.pl/Content/I22008/Audio/WA308 I52208 P366 Indonesian-Music-Cul ooooI.mp3.

I3 Rebana or terbang are typically played in an ensemble (of six to eight drums) in an interlocking style, to accompany the singing of songs in praise of God and the Prophet Muhammad, and in religious and ceremonial processions. 
there does not seem to be overt hostility toward it, some are hesitant to accept it as "proper" church music for worship. Those who do use kentrung not only accept it in the church, but also feel proud that this kind of music (simple and plain) can be used to glorify God. The members of the Christian kentrung ensemble that I worked with in Surakarta, in addition to frame drums, use instruments that are typically associated with traditional Javanese music: key-metallophones (saron), double-headed barrel drum (kendhang), kemanak ${ }^{14}$ and some European/Western instruments, including a violin, an ukulele (a small guitar) and occasionally a keyboard (see fig. 4). The reasons for using such a hybrid variety of instruments in the ensemble were very practical. These instruments were readily available to the ensemble's members at the time and were acceptable to an older generation with minimum education. They were also relatively inexpensive and portable (unlike most gamelan instruments). While the members of the ensemble did not view the usage of kentrung as wrong, inappropriate or unsuitable and treated it as an artistic medium in the worship of God, some Javanese musicians would not use kentrung for aesthetic reasons: the atmosphere of kentrung was perceived as too closely associated with Islamic religious elements.

Motivated by both religious and aesthetic considerations, some Christian composers strive to compose songs that are perceived as aesthetically distinct from traditional Javanese songs (for example, Wignyosaputro ${ }^{15}$ and Surono). Hence, the more common use of: the 7-tone pelog scale, which evokes the Western diatonic scale (and

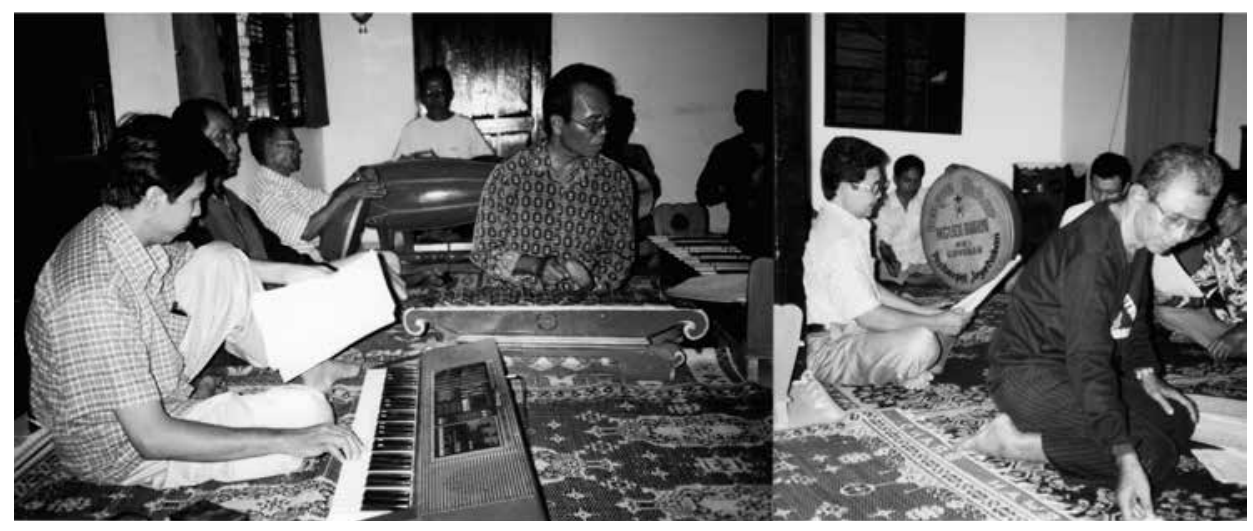

Rehearsal of a Protestant group (Joyotakan church, Surakarta)

I4 Kemanak is a pair of banana-shaped idiophones, one pitched higher than the other, and played in a hocketing manner.

I5 See M. Poplawska 2016. 


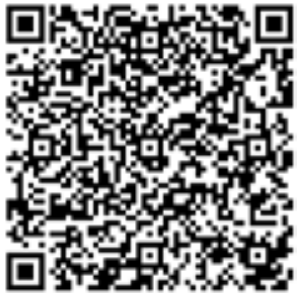

Audio recording 2

consequently church music ${ }^{16}$ ); unusual (for Javanese music) vocal lines ${ }^{17}$; changes to traditional poetic verses (e.g. by adding syllables); and Western techniques (e.g. harmony, canon), which implemented within traditional forms generate new acoustic, artistic and aesthetic results. All of these serve to create the overall feeling that the piece of music is no longer Javanese in character, even though performed by gamelan ${ }^{\mathrm{I}}$.

Guided by their rasa - artistic tastes and feelings about what is appropriate and what works well in a composition - Javanese Christian composers (for example, Surono, Sigit Astono, Is Sri) incorporate different musical elements and conduct experiments beyond the norms of tradition. They incorporate elements of various Indonesian regional traditions (for example, Sundanese and Balinese), use unconventional instrumentation (only selected gamelan instruments) and playing techniques. They try to conceptualize music and its role in the church, and to form a philosophical and aesthetic basis for their creative work in the field of church music.

Differing views and evaluations that arise from different rasa also concern newly composed (but traditional in nature) Catholic songs/hymns, created during composition workshops organized by the Center for Liturgical Music in Yogyakarta (Pusat Musik Liturgi or PML) ${ }^{19}$ in locations throughout Indonesia. The most problematic and contentious issue, rooted in the aesthetics of rasa, is the issue of arrangements of local melodies. Because most of the local traditions on Flores (an island in Eastern Indonesia) do not employ multiple melodies sung simultaneously, the origin of multipart singing on Flores is often attributed to a Western (church) influence. Similarly, the four-voice (choir) arrangements of tradition-based church songs were, at the outset, an imitation of Western style ${ }^{20}$.

I6 Pelog (being a 7-tone scale) uses smaller intervals than slendro. Because of that it is more akin to a Western/European diatonic scale. However, it still preserves the unique Javanese intonation, which does not equate to its Western counterpart.

I7 Traditional Javanese songs feature only one vocal part. Adding additional vocal parts changes the character of the piece. Wignyosaputro, for example, noted that after he added the second vocal part, the traditional character of the song disappeared. Moreover, vocal melodies of Christian songs are usually more elaborate and thus not predictable in the way that traditional gerong (male chorus) melodies in a traditional piece would be.

I8 Audio recording 2: A song in $3 / 4$, by Bapak D. Wignyosaputro, Surakarta: https://rcin.org.pl/Content/I22008/Audio/WA308 152208 P366 Indonesian-Music-Cul 00002.mp3.

I9 The Center is led by two people: a German Jesuit, Rama Karl Edmund Prier, and an Indonesian music educator, Bapak Paul Widyawan.

See John Ghono, interview. See also J. Kunst 1942 and 1946. 
The methods employed in compositional workshops are mostly Western. This at times generates contention, because certain features of traditional songs do not comply with Western theory, but are a part of indigenous practice. For example, the use of parallel fifths and octaves - generally discouraged in standard classical European polyphony - are unique characteristics of Ngada music from central Flores.

Some local musicians claim that in some of PML's arrangements and alterations, the final product is no longer recognizable to indigenous people. In their eyes, the arranged songs lose their uniqueness: they do not carry on tradition because the local idioms and nuances that are considered most important are not preserved. With an insensitive arrangement, the song's distinctiveness and individuality disappears and cannot be felt anymore. This is considered the biggest danger in adapting songs. In general, the various music experiments are accepted as long as they conform to local aesthetics ${ }^{21,22}$.

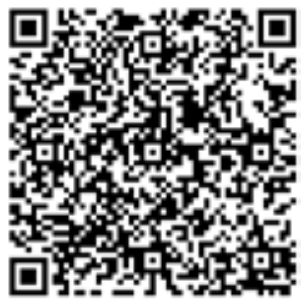

Audio recording 3

One other issue that is a potential source of conflicts, differences in opinion or even misinterpretations or misunderstandings is the need for simplicity. The Center for Liturgical Music intends for songs to suit the abilities of ordinary people: members of congregations. But "simplicity" may be defined differently, depending on the singing tradition of a particular location. In some cases, debates arise when the views on simplicity of the cultural "outsiders" (the team from the Center) differ from the perspective of cultural "insiders" (local musicians and teachers). What is deemed too difficult for a typical congregation may be part of an indigenous style commonly executed without any difficulty by local people. ${ }^{23}$

These examples show that different levels of musical/cultural competence generate different musical understandings, different rasa, and in consequence also different interpretations and meanings.

\section{MUSIC AND IDENTITY}

Identity can manifest itself in manifold ways. As Mendieta (2003, 4I3) notes, it "has defied and will continue to defy easy encapsulation by one or even a group of

2I The norms of acceptance are rather difficult to articulate. As in Java, the main criterion is music's pleasantness and enjoyable sound.

22 Audio recording 3: Song in traditional style, by Pater Pit Wani, Flores:

https://rcin.org.pl/Content/I22008/Audio/WA308 I52208 P366 Indonesian-Music-Cul 00003.mp3.

For a more detailed discussion of these issues, see M. Poplawska 2018. 
disciplines. For identity has to do with the most fundamental, but also wide-spanning, aspect of human existence."

Music, as a means of expression with many layers of culturally defined meaning, is a creative force in shaping identity, one nearly as powerful as ethnicity and language. It constructs people's sense of identity. It can draw distinctions and reinforce similarities. Music provides potential for change and reconfiguration of identity. Musical instruments, songs and musical styles may symbolize particular groups and communities, sometimes as a principal constituent of their identity. As Tim Rice notes, music's role in shaping identity is unique, for music has "the ability to index different aspects of multiple identities through the multiplicity of its formal properties (melody, harmony, rhythm, timbre and so forth)" (2007, 35).

While researching Christian traditional music in Indonesia, I was particularly interested in the music's capability to shape identity and to maintain community. In what ways people use music as a vehicle to express their individual, ethnic and religious identity; how Indonesian identities are constructed through music; and what is the role of music in negotiations of identity at various social levels: local or ethnic, regional, national, and global?

The issue of Christian Indonesian identity is rather complex. Christianity was brought to Indonesia by Europeans (the Portuguese in the $16^{\text {th }}$, Dutch in the $17^{\text {th }}$, and many more in the $20^{\text {th }}$ century). It was considered by some members of the Muslim majority as agama Belanda, the religion of the Dutch (that is, a foreign religion). This opinion was especially common before Indonesian independence from Dutch colonial power (1945), and continued to have a powerful effect, as Indonesian Christians were accused of being heirs to a colonial religion and spirit. ${ }^{24}$ After independence, several Catholic leaders made a conscious effort to integrate the Catholic community into the new Republic of Indonesia. The first Indonesian bishop and archbishop, Albertus Soegijapranata, was known for his motto: "A hundred percent Catholic, and a hundred percent Indonesian!" (Sunquist 200I, 786). ${ }^{25}$ Maintaining connections to their cultural and social environment has been a goal of the Christian community in Indonesia ever since. Its members aspire to be an integral part of the larger society and are striving to make a place for themselves within the Indonesian nation. The words on the message

24 In the $19^{\text {th }}$ century, indigenous Christians fell into two groups: Kristen Londo (Dutch Christians) and Kristen Jowo (Javanese Christians). The former group was most often supervised by Europeans and abandoned Javanese customs in exchange for European ones, while the latter - under the leadership of Javanese evangelists - tried to integrate Javanese customs into the Christian faith (see Kim 2004, 42-44 and Yoder 1987, 279). Contemporary Javanese Christians are successors of Kristen Jowo adherents.

This is not unusual for other ethnic groups as well. Daniel Reed (2005), for example, examines a case of Dan people in Cote d'Ivoire, who simultaneously proclaim strong ethnic and Catholic identities. 
board on the website of the Forum of the Catholic Indonesian Community of the Archdiocese of Jakarta express a political awareness, and a contemporary declaration of striving for a distinct identity: "We are fully Indonesian, fully Catholic, and we will stand up for our rights!"

Judith Becker affirms that music in Indonesia has always been centrally linked to religious faith (Harnish \& Rasmussen 20II, 352). Through a plurality of musical genres, which "offer a variety of templates and suggest multiple possibilities," Indonesian Christians (similarly to their Muslim counterparts) learn how to be Christian within an Asian (or Southeast Asian) context, how to relate to Euro-American Christianity and how to shape Indonesian Christianity. Through music performance, Indonesian Christians are making diverse statements about history, power, and cultural and social alliances, while continuously exploring their own communal and individual identities (see Rasmussen 20I0, 210).

Music performance plays a vital role in identity negotiations at all levels (local, regional, national, global). Christian local communities in Indonesia musically redefine themselves, while acting against social ostracism and re-establishing connections with society at large (see Wiebe 20I7). Performing local Christian music in churches is a way of claiming national space by Indonesian Christians (see fig. 5). It stems from the

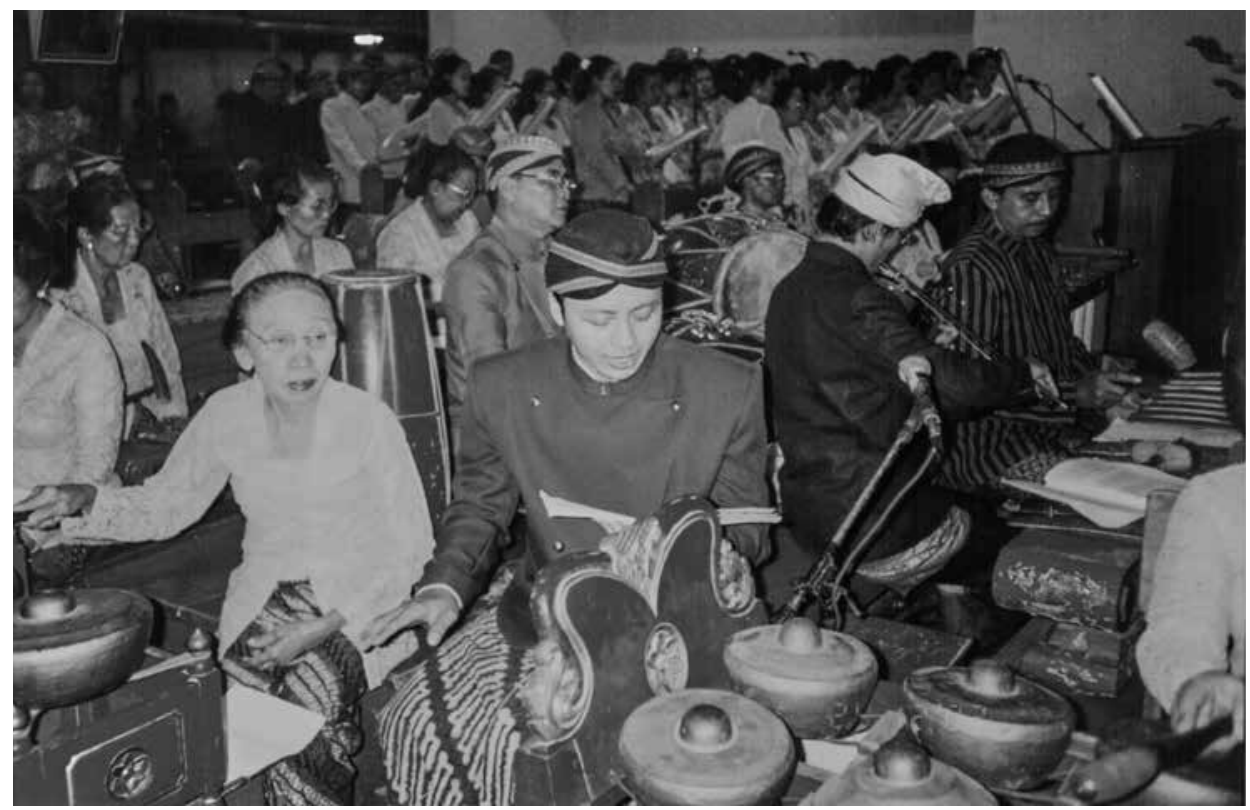

Gamelan group and choir, joined by a violin player (Purbowardayan Catholic church, Surakarta) 
desire to be active members of the Indonesian nation and society, and is part of an ongoing, long-term political debate that involves various religious minorities struggling to secure a place for themselves in modern Indonesia (see Steenbrink 2004).

The inclusion of traditional performing arts in the church has been central to the formation of Indonesian Christian identity ${ }^{26}$. It enables the Javanese and Florenese (and indigenous people in other geographic locations) to express their faith in a form that is most compatible with their local identities. It enables them to be Christian, and yet retain a sense of their own (local) cultural identity. In a symbolic sense, local Christian music might be viewed as an act of performative resistance to hegemonic power structures, such as the state or the church itself. When performing indigenous music, $19^{\text {th }}$ century Javanese Christians resisted colonial era missionary attempts to eradicate local cultural practice, while $2 \mathrm{O}^{\text {th }}$ century Javanese Christians have resisted the attempts of radical Muslims to conflate religious and ethnic identities into a uniform national identity (see Steenbrink 2015). ${ }^{27}$

In this paper, I have tried to show that music - humanly organized sound - is a complex and multifaceted phenomenon. It is an expression, which is simultaneously musical and cultural. As a realm of activity, it is located at the centre of social (and individual) lives. It constitutes a means by which communities define themselves. It is participatory, experiential, performative and embodied. Music researchers (anthropologists/ethnomusicologists) engage with music in a variety of modes: through listening, learning, teaching, researching and performing. Their experiences of music are equally personal, social and cultural.

\section{BIBLIOGRAPHY}

A r a g o n L. V. 1996. Suppressed and Revised Performances: Raego' Songs of Central Sulawesi, Ethnomusicology 40 (3), 413-438.

A r a g o L. V. 200o. Fields of the Lord: Animism, Christian Minorities, and State Development in Indonesia. Honolulu: University of Hawai'i Press.

B a r z G. F. 2003. Performing Religion: Negotiating Past and Present in Kwaya Music of Tanzania. New York: Rodopi.

B e r g e r H. M. 20I5. Phenomenological Approaches in the History of Ethnomusicology. Oxford Handbooks Online.

26 Not all Indonesian denominations incorporate traditional arts in an equal manner. Many Catholic churches and the Christian (Protestant) Javanese Church (Gereja Kristen Jawa) include traditional arts most methodically and extensively. Other churches do so to a lesser extent; it very much depends on a particular local church congregation.

27 See Reed (2005), who discusses in detail a case of performative resistance among Dan people in postcolonial Côte d'Ivoire. 
B erge r H. M. 2008. Phenomenology and the Ethnography of Popular Music: Ethnomusicology at the Juncture of Cultural Studies and Folklore. In T. Cooley \& G. Barz (eds.), Shadows in the Field, Second Edition. New York: Oxford University Press, 62-75.

B l a ck in g J. 1973. How Musical is Man? Seattle: University of Washington Press.

B r i n n e r B. 1995. Knowing Music, Making Music: Javanese Gamelan and the Theory of Musical Competence and Interaction, University of Chicago Press.

C o o le y T. J., B a r z G. (eds.). 2008. Shadows in the Field: New Perspectives for Fieldwork in Ethnomusicology, Second Edition. New York: Oxford University Press.

C o o l e y T. J. and B a r z G. 2008. Casting Shadows: Fieldwork Is Dead! Long Live Fieldwork! - Introduction. In T. Cooley \& G. Barz (eds.), Shadows in the Field, Second Edition. New York: Oxford University Press, 3-24.

Cottrell S. 2007. Local bimusicality among London's freelance musicians. Ethnomusicology, 5I(I), $85-105$.

Dí a z-A nd r e a u M. 2005. The Archeology of Identity: Approaches to Gender, Age, Status, Ethnicity and Religion. London, New York: Routledge.

D o m in gu e z V. R., Wu D. Y. H. (eds.). 1998. From Beijing to Port Moresby: The Politics of National Identity in Cultural Politics. Amsterdam: Gordon and Breach Publishers.

D u e ck J. 2016. The Oxford Handbook of Music and World Christianities, Oxford University Press.

F r i t h S. I996. Music and identity. In S. Hall, P. Du Gay (eds.), Questions of Cultural Identity. Thousand

Oaks, CA: Sage Publications, Inc., I08-127.

Ge e r t z C. 1960. Religion of Java. University of Chicago Press.

Giuriati G. 20or. Ki Mantle Hood. In Grove Music Online, L. Macy (ed.). Oxford University Press.

He r n d o n M. 1993. Insiders, outsiders: knowing our limits, limiting our knowing. The World of Music $35(\mathrm{I}), 63-8 \mathrm{O}$.

H o d g e s W. R. 2009. Ganti Andung, Gabe Ende (Replacing Laments, Becoming Hymns): The Changing Voice of Grief in the Pre-funeral Wakes of Protestant Toba Batak (North Sumatra, Indonesia). Ph.D. dissertation, University of California Santa Barbara.

Ho od M. 1960. The Challenge of Bi Musicality. Ethnomusicology 4(2), 55-59.

Ke a n e W. 2007. Christian Moderns: Freedom and Fetish in the Mission Encounter. Berkeley and Los`Angeles: University of California Press.

Ki m J. K. 2004. Mission Strategy for the Javanese Church of Tomorrow in the Province of Yogyakarta. Ph.D. dissertation, Biola University.

Ku n s t J. 1942. Music in Flores. A Study of the Vocal and Instrumental Music among the Tribes Living in Flores. Leiden: E. J. Brill.

Kun s t J. 1994 [1946] Indigenous Music and the Christian Mission. In Indonesian Music and Dance: Traditional Music and its Interaction with the West. Amsterdam: Royal Tropical Institute, 57-87.

L u c y S. 2005. Ethnic and cultural identities. In M. Diaz-Andreu, L. Sam, S. Babić, D. N. Edwards (eds.), Archaeology of Identity. London: Routledge, 86-109.

Manhart T. M. 2004. A Song for Lowalangi - The Interculturation of Catholic Mission and Nias Traditional Arts with Special Respect to Music. Ph.D. dissertation, National University of Singapore.

Meka V. A. G. 20I2. Katolicka kultura muzyczno-liturgiczna w regionie Manggarai na wyspie Flores (Indonezja). Ph.D. dissertation, Katolicki Uniwersytet Lubelski.

Men d i e t a E. 2003. Afterword: Identities: Postcolonial and Global. In L. M. Alcoff, E. Mendieta (eds.), Identities: Race, Class, Gender, and Nationality. Malden, MA: Blackwell Pub.

Merriam A. 1960. Ethnomusicology, Discussion, and Definition of the Field. Ethnomusicology I4, I07-I4. 
Me r r i a m A. 1964. The Anthropology of Music. Evanston: Northwestern University Press.

Merriam A. 1977. Definitions of 'Comparative Musicology' and 'Ethnomusicology': a historical theoretical perspective. Ethnomusicology 2I(2), I89-204.

$\mathrm{Mu} \mathrm{h}$ a m m a d M. et al. 20I5. Reflections on researcher identity and power: the impact of positionality on community based participatory research (CBPR) processes and outcomes. Critical Sociology $4 \mathrm{I}(7-8)$, IO45-IO63.

Net 1 B. 2005. The Study of Ethnomusicology: Thirty-one Issues and Concepts. New Edition. Urbana: University of Illinois Press.

Notosudirdjo F. S. 20or. Music, Politics, and the Problems of National Identity in Indonesia. Ph.D. dissertation, University of Wisconsin-Madison.

$\mathrm{O} k$ a z a k i Y. 1994. Music, Identity, and Religious Change among the Toba Batak People of North Sumatra. Ph.D. dissertation, University of California.

Pe r $1 \mathrm{~m}$ a n M. 1994. American Gamelan in the Garden of Eden: Intonation in a Cross-Cultural Encounter. The Musical Quarterly, 78(3), 510-555.

Poplawska M. 2004. Wayang Wahyu as an example of Christian forms of shadow theatre. Asian Theatre Journal 2I(2), 194-202.

Poplawska M. 20II. Christianity and inculturated music in Indonesia. Southeast Review of Asian Studies 33, I86-198.

Po p la w sk a M. 2016. New Christian music in Indonesia: inculturation in transition. In P. Bohlman, J. Engelhardt (eds.), Resounding Transcendence: Transitions in Music, Religion, and Ritual. New York: Oxford University Press, III-I25.

Po plaw sk a M. 20I8. Inculturation, institutions, and creation of localized Congregational repertoire in Indonesia. In M. Ingalls, M. Swijghuisen Reigersberg, Z. Sherinian (eds.), Locating Christian Congregational Music: Indigeneity, Cosmopolitanism, and Diversity. Abingdon, New York: Routledge, $133-158$.

Po plaw ska M. 2020. Performing Faith: Christian Music, Identity and Inculturation in Indonesia. Abingdon, New York: Routledge.

R a p p o p o r t D. 2004. Ritual music and Christianization in the Toraja Highlands, Sulawesi. Ethnomusicology 48(3), 378-404.

R a smussen A. K. 2004. Bilateral negotiations in bimusicality: insiders, outsiders, and the "real version" in Middle Eastern music performance. In T. Solís (ed.), Performing Ethnomusicology. Berkeley and Los Angeles: University of California Press, 2I5-228.

Rice T. 2008. Toward a mediation of field methods and field experience in ethnomusicology. In T. Cooley and G. Barz (eds.), Shadows in the Field, Second Edition. New York: Oxford University Press, 42-6I.

Rice T. 2007. Reflections on music and identity in ethnomusicology, Muzikologija 7, I7-38.

$\mathrm{S}$ h el e $\mathrm{m}$ a y $\mathrm{K}$ a u f m a n, K. 2008. The ethnomusicologist, ethnographic method, and the transmission of tradition. In T. Cooley \& G. Barz (eds.), Shadows in the Field. New York: Oxford University Press.

Sh el e m a $\mathrm{K}$ a u fm a n K. 20oI. Soundscapes: Exploring Music in a Changing World. New York and London: W. W. Norton \& Company.

Sl o b i n M. 1994. Music in diaspora: the view from Euro-America. Diaspora: A Journal of Transnational Studies 3(3), 243-25I.

$\mathrm{S} \mathrm{m}$ i t h L. T. 20I2. Decolonizing Methodologies: Research and Indigenous Peoples, Second edition. London: Zed Books.

S o lís T. (ed.). 2004. Performing Ethnomusicology: Teaching and Representation in World Music Ensembles. Berkeley and Los Angeles: University of California Press. 
S o lís T. 2004. Introduction. Teaching what cannot be taught: an optimistic overview. In T. Solís (ed.), Performing Ethnomusicology. Berkeley and Los Angeles: University of California Press.

$\mathrm{S}$ t e e n b r in k K. 2015. Catholics in Independent Indonesia: 1945-2010. Brill.

S t o k e s M. (ed.). 1994. Ethnicity, Identity and Music: The Musical Construction of Place. Oxford/Providence, USA: Berg Publishers.

S u n q u i s t S. W., W. B. Eerdmans (eds.). 200I. A Dictionary of Asian Christianity, Michigan: Publishing Company.

Tit o n J. T. 2008. Knowing fieldwork. In T. Cooley \& G. Barz (eds.), Shadows in the Field, Second Edition. New York: Oxford University Press, 25-4I.

Tu r i n o T. 2008. Music as Social Life: The Politics of Participation. Chicago: University of Chicago Press.

Warden N. 20I6. Ethnomusicology's "identity" problem: the history and definitions of a troubled term in music research, El oido pensante 4(2). Retrieved from http://ppct.caicyt.gov.ar/index.php/oidopensante.

W i e b e D. 2017. Contextual Church Reform and the Secularization of 'Sacred' Balinese Music and Dance: Forging Protestant/Hindu Music Networks in an Age of Mass Tourism. Ph.D. dissertation, Wesleyan University.

Wilf red F. (ed.). 20I4. The Oxford Handbook of Christianity in Asia, New York: Oxford University Press.

Wo n g D. 2008. Moving: from performance to performative ethnography and back again. In T. Cooley \& G. Barz (eds.), Shadows in the Field, Second Edition. New York: Oxford University Press.

Yoder McCulloh L. 1987. The Introduction and Expression of Islam and Christianity in the Cultural Context of North Central Java. Ph.D. dissertation, Fuller Theological Seminary, School of World Mission.

\section{Author's contact:}

Marzanna Popławska

Institute of Ethnology and Cultural Anthropology

University of Warsaw, Poland

E-mail: m.poplawskai $3 @ u w . e d u . p l$

ORCID : oooo-0oo2-0734-7758

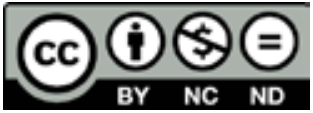


